\title{
Main considerations on the use of biomembranes in implantology: A review
}

\author{
Lília Regina Cardoso Prates ${ }^{1}$, Idiberto José Zotarelli Filho ${ }^{2 *}$ and Ávaro José Cicarelli ${ }^{1}$ \\ ${ }^{1}$ Associação Paulista De Cirurgiões Dentistas de São José do Rio Preto/SP, Brazil \\ ${ }^{2}$ Post graduate and continuing education (Unipos), Street Ipiranga, 3460, São José do Rio Preto SP, Brazil
}

\begin{abstract}
Over the past 30 years, the number of dental implant procedures has been increasing worldwide, reaching about one million dental implants per year. In Brazil, in the last decades, there has been a very rapid evolution in implant dentistry with high success rates. The development of biomaterials for use in dental clinics in recent years has represented a powerful therapeutic tool in the correction of bone defects. This study aims to analyze and discuss the main types of biological membranes, positives, negatives, their indications and results. For the development of the present revision work, we used a database such as Medline, Embase, Pubmed, Ovid and Cochrane. The main descriptors (MeshTerms) used were "Implantology", "Regenerative Surgery", "Biomembranes", "Bioengineering Bone". Based on the literary findings, both non-absorbable and absorbable membranes are effective in the process of bone regeneration. Absorbents do not require a second surgical time. However, there are information gaps, and further research is needed to ensure the perfect knowledge of the properties of the physical barriers to achieve a perfect bone regeneration of the periodontal bone defects and around implants. Due to bone regeneration and biological barriers in the Grafting surgeries, there was a technological growth of these materials because they pointed out as potential tools for the treatment of bone loss.
\end{abstract}

\section{Introduction}

The number of dental implant procedures has been increasing worldwide, reaching about one million dental implants per year $[1,2]$. In Brazil, in the last decades, there has been a very rapid evolution in the Implantodontia with high success rates [3]. The development of biomaterials for use in dental clinics in recent years has represented a powerful therapeutic tool in the correction of bone defects [3]. A study of 133 dental surgeons using biomaterials showed that professionals are not aware of the risks and benefits of biomaterials, nor of their biological principles, since $45 \%$ believe there is no risk to the patient and $59 \%$ do not consider Biomaterial as medicine. About $76 \%$ felt secure with respect to the origin [3]. Despite this, $95 \%$ of respondents said that there should be greater control of health authorities. More than half of the interviewees (51\%) reported little or no patient participation in the process of therapeutic choice [3].

Many patients, elderly or not, sought implant-supported rehabilitation, but there is a need for some adjustments that lead to the consequent demand for regenerative procedures for maxillary reconstructions $[4,5]$. These patients can often present pathological changes, or make use of medications, which may alter bone healing [5-7]. Several materials can be used as a bone graft, each with different properties; For example: for neovascularization, materials such as hydroxyapatite and calcium phosphate showed the highest expression rates of vascular growth factors (VEGF) and microvascular density; While the polymer grafts showed the lowest rates [8].

The main problem is with non-absorbable membranes, because they require a second surgical act, they provide infections if there is any type of exposure; Have a consistent consistency, which makes it difficult to adapt to the bone defect and thus impairs blood supply and can cause dehiscence and tissue necrosis [5-7].
This study aims to analyze and discuss the main types of biological membranes their indications and results.

\section{Methods}

For the development of the present review, we used a database such as Medline, Embase, Pubmed, Ovid and Cochrane. The main descriptors (MeshTerms) used were "Implantology", "Regenerative Surgery", "Biomembranes", "Bioengineering Bone" (Figure 1).

\section{Literary review}

\section{Epidemiology and justification}

According to data from the Brazilian organ transplant association, the number of bone transplants per million population reaches 19,000 transplants in the State of São Paulo, 4,100 in the State of Paraná and 1,200 in the State of Rio de Janeiro, made available by the 5 Tissue Banks of the 3 States, during the $10^{\text {th }}$ quarter of 2012 [8-13].

The lack of bone in the alveolar ridges has been a major problem in functional aesthetic recovery in patients who have suffered dentoalveolar trauma, traumatic dental extractions, congenital dental absence, pathologies involving maxilla and mandible, as well as infections due to the emotional and Possibility of deformity and also the economic impact they cause in the National Health System (NHS) $[11,13]$.

Correspondence to: Dr. Idiberto José Zotarelli Filho, Unipos - Post graduate and continuing education, Street Ipiranga, 3460, São José do Rio Preto SP, Brazil, Tel: +55(17) 98166-6537/+55(17) 98803-7459; E-mail: m.zotarelli@gmail.com

Key words: implantology, regenerative surgery, biomembranes, bioengineering bone

Received: July 28, 2017; Accepted: August 16, 2017; Published: August 19, 2017 


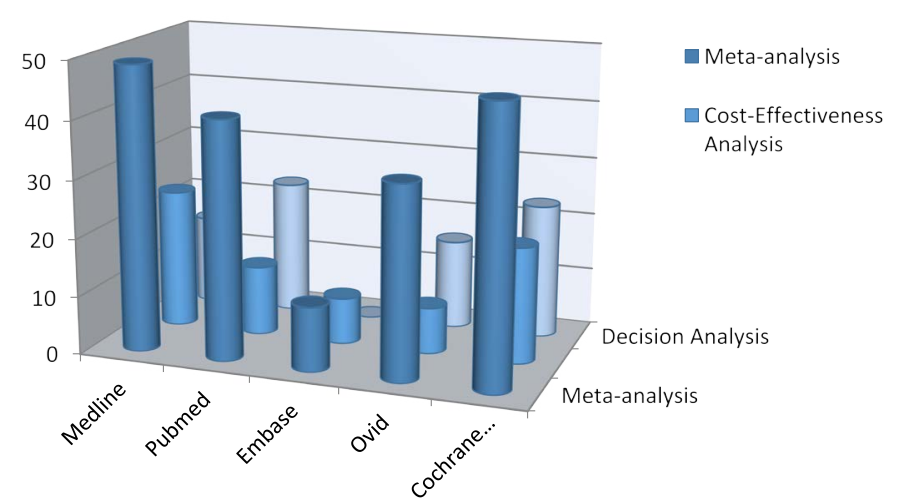

Figure 1. Quantification as a percentage of the recent papers published in the mentioned journals.

Bone loss can also occur due to periodontal disease, traumatic surgeries, or even for physiological reasons due to lack of adequate bite function or prosthetic load [14]. The trauma in the face region can reach both the soft tissues (skin, muscles, nerves) and hard tissues (bones, teeth), so these lesions can affect the quality of life as well as the health of the victim [14].

The trauma maxillofacial injury can be considered one of the most devastating aggressions found in traumatology and oncology, due to the emotional consequences and the possibility of deformity and also the economic impact they cause in the National Health System (NHS) [15-18]. The face, more than any other region of the body, is affected by aesthetic changes, since it is always visible, and damages are perceived immediately [19-25]. For this reason, the trauma of the face deserves attention in the treatment of polytrauma due to its high incidence and severity.

\section{Bone engineering}

The bone structure consists of osteoprogenitor cells, support osteoblasts and osteocytes, remodeling cells - osteoclasts - and a nonmineralized extracellular matrix called the osteoid, composed of type I collagen and non-collagen proteins such as osteonectin, osteocalcin, Morphonetic bone protein (BMP), glycosaminoglycans (GAG) and bone sialoproteins [26-29].

The osteoprogenitor cells are small spindle cells found on all nonresorbable bone surfaces, derived from primitive mesenchymal cells and form a population and precursor cells that can differentiate into more specialized cells such as osteoblasts and osteocytes [15].

Regeneration of composite tissues such as periodontal tissue has also been demonstrated, proving that adipose stem cell associated with platelet rich plasma can regenerate alveolar bone, cementum and periodontal ligament eight weeks after implantation [22,23]. Osteoblasts are derived from undifferentiated stem-cells and are responsible for the production of bone matrix, rich in collagen (mainly type I) and essential for subsequent mineralization, by adherence of calcium hydroxyapatite crystals, magnesium, potassium, sodium and Carbonate in collagen fibrils $[10,20]$.

The osteoinduction process is influenced by several factors and consists in the induction of mesenchymal stem cells of adipose tissue in osteoprogenitor cells $[15,25]$. Osteogenic differentiation requires the presence of inducers, which include $\beta$-glycerolphosphate, ascorbic acid and dexamethasone [25].

Further, $\beta$-glycerolphosphate, promote osteogeny by their function in mineralization and modulation of osteoblast activity [15]. Thus, free phosphates can induce mRNA and protein expression, exemplified by the osteopontin protein. If organic phosphate, for example $\beta$-glycerolphosphate is present, the formation of a mineral content occurs, hydroxyapatite that is formed between the collagen fibers [21].

Moreover, Bone morphogenetic proteins function as growth factors with a specific role in the proliferation and differentiation of mesenchymal stem cells from adipose tissue [17,24]. BMP-4 is involved in the early stages of osteogenesis; in addition, it has been shown that the differentiation of human adipose mesenchymal stem cells into the osteogenic lineage requires the presence of BMP-4 in the first days of culture and that these cells, after 21 Days express specific proteins of the osteogenic lineage such as osteonectin, osteocalcin and osteopontin [24].

Thus, tissue engineering is a tool that makes possible through a suitable biological niche the construction and regeneration of any tissues and organs $[18,27]$. For this, xenografts, autografts and allografts are used, with and without the use of cells $[13,14]$. According to the Conference of the National Institute for the Development of Health Consensus in 1982, biomaterials are beneficial organic compounds, or a combination thereof, that can be used for a period of time, wholly or partially as part of a system that treats, Replace any tissue, organ or function of the human body $[18,27,30]$.

\section{Biomaterials in dentistry}

Due to the great technological development of biomaterials, associated with the advancement of knowledge about the biology of bone tissues, it has become possible to selectively influence bone formation, controlling the quality and quantity of bone inside the buccal structures [31]. Thus, ancient records show us the use of substances, such as ivory. Dry bone, gold, gold wire, silver alloys, among other materials. From 1800, it is observed the use of synthetic compounds for bone replacement, when researchers advocated the use of calcium sulfate in bone defects [31].

In this way, there is a wide variety of biomaterials, synthetic or biological, with variable particle sizes and mainly classified according to their mode of action: osteoconduction, osteoinduction or osteogenesis. In implantology, implant placement should be used as complementary therapy, and it is necessary to know the biological potential of each material to indicate it in the various clinical situations [31].

We can find in the market a varied range of biomaterials, such as demineralized lyophilized bone, anorganic bone and bioactive glass. These biomaterials should have precise indications and should not require unreal biological demands from them. It is known that bone neoformation is a biological process that happens at the expense of osteoblastic activity and that the quality of the neoformed tissue, when in the presence of these biomaterials, is not the same for all, and depends on the material, its origin, clinical conditions the recipient site, the field of indications and the surgical technique [31].

\section{Maintenance of alveolus size}

The concern of the implantant after the extraction, is the bone loss in volume of the alveolus [31-33]. When it is not possible to install immediate implants, after exodontia, the alveolar process, depending on the thickness of the buccal bone board at the end of the bone remodeling process, may present depression on the vestibular surface, which would imply the need for block autogenous graft [33]. In a study carried out in 1967, it was observed that in the anterior maxilla there is loss of $25 \%$ of bone volume in the first year after exodontia. In the posterior region, it is twice as large as in the anterior maxilla [34]. 
It is believed that if the bone defect is five walls the alveolar bone repair will happen naturally. However, if the vestibular wall is less than $1.5 \mathrm{~mm}$ thick or absent, the practitioner should use intra-alveolar materials (autogenous bone, mineralized bone or alloplastic material), associated with membranes that improve the predictability of Restoration of the original bone contour in the alveolar process $[35,36]$. There is an indication of the technique called Bio-col for preservation of alveolar bone walls.

Regarding the use of bone-guided regeneration, a study confirmed bone ridges after exodontia with and without the use of biological membranes. After six months, bone crest loss of $0.38 \mathrm{~mm}$ versus 1.50 $\mathrm{mm}$ and horizontal bead reabsorption of $1.31 \mathrm{~mm}$ versus $4.56 \mathrm{~mm}$ respectively were observed.

For a better predictability of the guided bone regeneration technique there is a requirement that the membrane be totally protected by the mucoperiosteal flap and that, in the presence of teeth, it is at least $1 \mathrm{~mm}$ away from the periodontal space [37]. It is also necessary that the biological space be maintained by membrane memory, or that the membrane be supported by the interdental septal bone structure, or by the remainder of the alveolar bone walls. If this condition does not exist, autogenous particulate bone, mineralized or synthetic biomaterial can be used [38].

\section{Guided bone regeneration}

It is used for correction of defects, when it is desired, increase of bone volume, for this it is necessary, that the tissue recomposes cells with characteristics of the region without interference of the connective tissue [32]. Guided tissue regeneration promotes selective cellular response without producing an inflammatory reaction. Its use presents a degree of specificity to the type of tissue where it will be performed [32].

Guided bone regeneration is the technique that uses osteopromotion as a biological principle. It is indicated for bone regeneration in fresh alveoli, bone defects that have remaining bone walls, to promote bone neoformation around implants installed immediately after extraction, to correct bone loss (Peri-implant) that occurred after osseointegration [31].

\section{Biological membrane for bone neoform and characteristics}

It should function as a physical support to the surrounding soft tissue, preventing the collapse of this space that will be filled by the blood clot, necessary for bone formation. It should also possess permeability that allows diffusion of plasma and nutrients, but which prevents the passage of non-osteogenic cells, in addition to having biocompatibility integration with the host tissue without creating inflammatory responses [32].

The first membranes to be successfully used in bone regeneration were expanded polytetrafluoroethylene, non-resorbable. The eventuality of exposure posed a risk of infection, requiring premature removal. Due to this inconvenience, they developed resorbable membranes, collagen or polylactic acid polymers [32].

They must have good tissue integration, ensuring the growth of cells without crossing the material; Prevent the early migration of the epithelium on the outer surface of the material or encapsulation of the material; To provide stability to the suprajacent retail; Be available in easy configuration for better adaptation; Present selectivity (passage of nutrients, gases) and have occlusive property. The right choice of membrane to take advantage of its basic characteristics will depend on the operator's ability and his mastery with the material [32].
Fine membranes are used when the need is only for insulation of the site. Medium membranes are used for insulation, and should have greater or lesser degree of strength and stiffness according to the imposed deformation. Thick membranes confer structural action, creating ample space and sustaining in adverse conditions.

\section{Non-absorbable biomembranes}

They are formed by overlapping layers of Teflon, of highly ordered structure, giving a controlled porosity that allows passage of liquids. They consist of two parts, a peripheral part of greater porosity and flexibility, which guarantees the adaptation to the margins of the bone defects and another part of less permeability with greater rigidity.

The disadvantages of non-absorbable membranes are the need for additional surgical intervention for their removal and possible complications associated with membrane exposure, leading to infections, requiring removal and disruption of the regenerative process [32].

Expanded polytetrafluoroethylene membranes do not trigger inflammatory reaction, foreign body, has autoclave resistance, insoluble to a range of enzymatic solvents, has elasticity similar to bone tissue. It is reinforced with titanium and indicated for situations in which the formation of bone with great defects is desired.

They are composed of double layer polytetrafluoroethylene expanded with titanium interposed. These barriers incorporate into their structure a skeleton, formed by a thin titanium blade. Titanium membranes are capable of promoting the formation of significant amount of new bone and maintaining sufficient space without the use of a support device [32].

\section{Reabsorbable biomembranes}

Reabsorbable membranes eliminate the need for additional surgery. They are classified in: natural and synthetic. They are degraded by the body through enzymatic hydrolysis, triggered by the inflammatory infiltrate that forms around the material. Collagen-based membranes are widely used today. Its efficacy is demonstrated by studies, however there is disagreement as to its use. They have their origin: bovine, swine and derived from the dura mater of the human brain, collected and submitted to the lyophilization process to eliminate antigenic substances. Before its positioning, it must be hydrated by immersion of the membrane in saline.

The resorbable membranes, diverts the body's attention to a process, which is its own removal from the site. Alumina is an alloplastic membrane that presents characteristics of passivity in the scarring process, makes isolation, spacing and stabilization, and does not generate any mechanism capable of altering the process.

The autogenous graft is considered the best because it guarantees predictable results, due to the lower rejection rate. Due to this, when coated with membrane, the autogenous bone can reach $50 \%$ of the original bone volume in up to six months. Bovine bone, when associated with non-absorbable membranes, begins the resorption process from the seventh month, and has a significant effect on bone filling parameters after a period of nine months [32].

\section{Discussion}

In this context, the use of biomaterials and membranes contribute to an optimized outcome in the rehabilitations with osseointegrable implants. Another prospective 3-year study in patients receiving platform switching implants indicated predictability of the technique 
associated with guided bone regeneration for aesthetic area reconstruction [34]. In a 10-year longitudinal prospective study, they indicated the possibility of gingival retraction in a group of patients who did not receive guided bone regeneration when compared to a group of patients who received the guided bone regeneration technique.

Based on the literary findings, both non-absorbable and absorbable membranes are effective in the process of bone regeneration. Absorbents do not require a second surgical time [33,34]. However, there are information gaps, and further research is needed to ensure a perfect knowledge of the physical barrier properties to achieve a perfect bone regeneration of the periodontal bone defects and around implants [34-36].

Regarding the use of the biomaterial, clinical studies have indicated predictability of the technique [34,35]. Another study showed in a randomized controlled clinical study that the guided bone regeneration technique using different biomaterials (Bone Ceramic / Bio-Oss) presented predictability and that both materials are suitable for preserving width and interproximal bone height of the collar Alveolar [18,28].

Another important aspect is the creation of a provisional implanted implant, since this prosthesis presents several functions such as adaptation of the patient, choice of color and shape, allowing gingival conditioning that besides obtaining aesthetics, such conduct represents less clinical time to the prosthetist During the final restoration phase [34-36].

Moreover, gingival conditioning allows the adjacent soft tissues to be directed during the osseointegration phase, thus avoiding gingival targeting maneuvers for esthetics [33]. The use of biomaterials in dentistry occurs on an increasingly wide scale. Several studies have demonstrated the synthesis of new biomaterials applied in all areas of dentistry with promising results [33-35].

Thus, the use of biomaterials at a clinical level should essentially be analyzed through the entire scientific evaluation process, ranging from in vitro laboratory tests to longitudinal clinical studies in vivo. Thus, the development of bioceramics and prostheses constituted by these materials must occur under the same interdisciplinary conditions that determine the development of any other dental material [19].

Further, there is a need to know all the properties mentioned here by the Dentist, so that there is a critical discussion about the use of biomaterials, avoiding only commercial information that is often incomplete and superficial $[19,34]$. The opportunity to discuss the use of biomaterials in dentistry, through the science of dental materials, expands the knowledge of this subject for professionals and researchers [19].

The diversity of applications of biomaterials, as well as their chemical, physical, biological and morphological differences, makes the research in this area of knowledge a work with eminently interdisciplinary characteristics. Within this context, professionals in the field of Materials Engineering can contribute significantly to the evolution of this area and to increase the range of its applicability, through the development of new and effective biomaterials and also in the elucidation of the mechanisms that govern the Bone regeneration [34-37].

\section{Conclusion}

Because biological barriers in graft surgeries, there has been a technological growth of these biomaterials because they are pointed as potential tools for the treatment of bone loss. It is necessary for the professional to be careful in its use by assessing the advantages and disadvantages by means of prospective and randomized clinical studies and with increase of size sample.

\section{References}

1. Pye AD, Lockhart DE, Dawson MP, Murray CA, Smith AJ (2009) A review of dental implants and infection. J Hosp Infect 72: 104-110. [Crossref]

2. Brånemark PI, Hansson BO, Adell R, Breine U, Lindström J, et al. (1977) Osseointegrated implants in the treatment of the edentulous jaw. Experience from a 10-year period. Scand J Plast Reconstr Surg Suppl 16: 1-132. [Crossref]

3. Bugarin Júnior JG, Garrafa V (2007) Bioethics and biosafety: the use of biomaterials in dental practice. Rev Saude Publica 41: 223-228. [Crossref]

4. Mazaro JVQ, Godoy PAI, Junior JFS, Mello CC, Pellizzer EP, Zavanelli AC (2014) Regeneração óssea guiada em implantodontia: relato de caso ; RFO, Passo Fundo.

5. Busetti J (2015) Avaliação histológica e histomorfométrica da regeneração óssea guiada sob membranad]s biológicas não reabsorvíveis em ratas osteoporóticas com e sem tratamento com ácido zoledrônico; Porto Alegre.

6. Fernandes TBG (2015) Utilização de membranas absorvíveis e não absorvíveis em técnicas de regeneração óssea na implantodontia; Uberlândia.

7. Costa JBZ, Silva F, Dultra CA, Souza LF, Santos MCNE (2016) Uso de membranas biológicas para regeneração óssea guiada em implantodontia - uma revisão de literatura - Revista Bahiana de Odontologia. 7: 14-21.

8. Saghiri MA, Asatourian A, Garcia-Godoy F, Sheibani N (2016) The role of angiogenesis in implant dentistry part II: The effect of bone-grafting and barrier membrane materials on angiogenesis. Med Oral Patol Oral Cir Bucal 21: e526-537. [Crossref]

9. Covani U, Chiappe G, Bosco M, Orlando B, Quaranta A, et al. (2012) A 10-year evaluation of implants placed in fresh extraction sockets: a prospective cohort study. $J$ Periodontol 83: 1226-1234. [Crossref]

10. Calasans MD, Fernandes GVO, Granjeiro JM (2011) Preservação alveolar com enxertos após exodontias e previamente à instalação de implantes. Revista Implantnews 6: $583-590$.

11. Fontanari LA, Manne JM, Junior WT (2007) Utilização de enxerto homógenos para reconstrução em áreas atróficas pré-implante: banco de ossos. Revista Implantnews 5: 539-597.

12. Gimble JM, Katz AJ, Bunnell BA (2007) Adipose-derived stem cells for regenerative medicine. Circ Res 100: 1249-1260. [Crossref]

13. Hallman M, Cederlund A, Lindskog S, Lundgren S, Sennerby L (2001) A clinical histologic study of bovine hydroxyapatite in combination with autogenous bone and fibrin glue for maxillary sinus floor augmentation. Results after 6 to 8 months of healing. Clin Oral Implants Res 12: 135-143. [Crossref]

14. Hing KA (2004) Bone repair in the twenty-first century: biology, chemistry or engineering? Philos Trans A Math Phys Eng Sci 362: 2821-2850. [Crossref]

15. Langer R, Vacanti JP (1993) Tissue engineering. Science 260: 920-926. [Crossref]

16. Lima AF (2008) Martorelli. Enxertos ósseos: características de alguns materiais Revista ABO Nacional 16.

17. Zago MA. Covas DT (2006) Células-tronco: Origens e Propriedades. In: Célulastronco: A nova Fronteira da medicina. Ed. M. Zago e D. T. Covas, pp. 3-20. Editora Atheneu São Paulo, Brazil.

18. Maiorana C, Sommariva L, Brivio P, Sigurtà D, Santoro F (2003) Maxillary sinus augmentation with anorganic bovine bone (Bio-Oss) and autologous platelet-rich plasma: preliminary clinical and histologic evaluations. Int $J$ Periodontics Restorative Dent 23: 227-235. [Crossref]

19. Mazzoneto R (2009) Reconstruções em Implantodontia - Protocolos clínicos para o sucesso e aprevisibilidade. Ed. Napoleão, 2009, 1ªEdição. Nova Odessa - SP, Brazil.

20. Aubin JE, Liu F (1996) The osteoblast lineage. In: Bilizekian, J., Raisz, L., and Rodan, G., editors. Principles of Bone Biology. San Diego, CA: Academic Press: 39-50.

21. Liu Y, Clark RAF, Huang L, Rafailovich MH (2010) Hyaluronic acid-gelatin fibrous scaffold produced by electrospinning of their aqueous solution for tissue engineering applications. In Advances inMaterial Design for Regenerative Medicine, Drug Delivery and Targeting/Imaging 1140: 131-136.

22. Beyer Nardi N, da Silva Meirelles L (2006) Mesenchymal stem cells: isolation, in vitro expansion and characterization. Handb Exp Pharmacol 249-282. [Crossref]

23. Locke M, Windsor J, Dunbar PR (2009) Human adipose-derived stem cells: isolation, characterization and applications in surgery. ANZ J Surg 79: 235-244. [Crossref] 
24. Vacanti JP, Langer R (1999) Tissue engineering: The design and fabrication of living replacement devices for surgical reconstruction and transplantation. Lancet 354: 32-34. [Crossref]

25. Mesimäki K, Lindroos B, Törnwall J, Mauno J, Lindqvist C, et al. (2009) Novel maxillary reconstruction with ectopic bone formation by GMP adipose stem cells. Int J Oral Maxillofac Surg 38: 201-209. [Crossref]

26. Chan YL, King NM (2009) Use of focused íon bean milling for investigating the mechanical properties of biological tissues: A study of human primary molars. Journal of the Mechanical Behavior of Biomedical Materials 2: 375-383.

27. Fardin AC (2010) Enxerto Ósseo em Odontologia: Revisão de Literatura. Innov Implant J, Biomater Esthet, São Paulo.

28. Zotarelli Filho IJ, Frascino LF, Greco OT, Araujo JDD, Bilaqui A, et al. (2013) Chitosancollagen scaffolds can regulate the biological activities of adipose mesenchymal stem cells for tissue engineering. J Regen Med Tissue Eng 2: 12

29. Simonpieri A, Del Corso M, Vervelle A, Jimbo R, Inchingolo F, et al. (2012) Current knowledge and perspectives for the use of platelet-rich plasma (PRP) and plateletrich fibrin (PRF) in oral and maxillofacial surgery part 2: Bone graft, implant and reconstructive surgery. Curr Pharm Biotechnol 13: 1231-1256. [Crossref]

30. Tejero R, Anitua E, eOrive G (2014) Toward the biomimetic implant surface: Biopolymers on titanium-based implants for bone regeneration. J Progress Polimeral Sci 39: 1406-1447.

31. Carvalho PSP, Rosa AL, Bassi APF, Pereira LAVD (2010) Biomateriais aplicados a implantodontia. Revista Implantnews 7: 56-65.
32. Pereira IKC, Fernandes JRS, Melo ITS (2013) Uso de membranas como barreiras protetoras de enxertos ósseos utilizados na implantodontia. Caderno de Ciências Biológicas e da Saúde. Boa Vista.

33. Caballé-Serrano J, Sawada K, Schuldt Filho G, Bosshardt DD, Buser D, Gruber R (2015) Bone conditioned medium: Preparation and bioassay. J Vis Exp 8: e52707. [Crossref]

34. Merli M, Merli I, Raffaelli E, Pagliaro U, Nastri L, et al. (2016) Bone augmentation a implant dehiscences and fenestrations. A systematic review of randomised controlled trials. Eur J Oral Implantol 9: 11-32. [Crossref]

35. Moschouris P, Retzepi M, Petrie A, Donos N (2017) Effect of Wnt3a delivery on early healing events during guided bone regeneration. Clin Oral Implants Res 28: 283-290. [Crossref]

36. Caballé-Serrano J, Sawada K, Miron RJ, Bosshardt DD, Buser D, Gruber R (2016) Collagen barrier membranes adsorb growth factors liberated from autogenous bone chips. Clin Oral Implants Res 28: 236-241. [Crossref]

37. Saghiri MA, Asatourian A, Garcia-Godoy F, Sheibani N (2016) The role of angiogenesi in implant dentistry part II: The effect of bone-grafting and barrier membrane materials on angiogenesis. Med Oral Patol Oral Cir Bucal 21: e526-537. [Crossref]

38. Fujioka-Kobayashi M, Sawada K, Kobayashi E, Schaller B, Zhang Y, Miron RJ (2016) Recombinant human bone morphogenetic protein 9 (rhBMP9) induced osteoblastic behaviour on a collagen membrane compared with rhBMP2. J Periodontol 11: 1-14. [Crossref]

39. Dai Z, Shu Y, Wan C, Wu C (2015) Effects of pH and thermally sensitive hybrid gels on osteogenic differentiation of mesenchymal stem cells. J Biomater Appl 29: 1272 1283. [Crossref]

Copyright: $\odot 2017$ Prates LRC. This is an open-access article distributed under the terms of the Creative Commons Attribution License, which permits unrestricted use, distribution, and reproduction in any medium, provided the original author and source are credited. 